International Journal of Social Science And Human Research

ISSN(print): 2644-0679, ISSN(online): 2644-0695

Volume 03 Issue 11 November 2020

DOI: 10.47191/ijsshr/v3-i11-04

Page No 261-265

\title{
Perception of the Need for Children's Comic Media Development with the Themes of Prevention of Covid-19 in Elementary School Learning
}

\author{
Munjiatun ${ }^{1}$, Guslinda ${ }^{2}$, Otang Kurniaman ${ }^{3}$, Eddy Noviana ${ }^{4}$, Muhammad Ramadhan ${ }^{5}$ \\ 1,2,3,4,5 Primary Teacher Education, Universitas Riau- Indonesia
}

\begin{abstract}
Analysis of perceptions of needs in developing children's comic media with the theme of preventing Covid-19 has a research objective to determine the needs of teachers in the development of children's comics. The research method used is quantitative methods, with the research instrument using google form as a research data collection tool, the results of research on the use of comic media in learning in elementary schools were the highest with the criteria of $55.2 \%$, and in the category of never using comic media as many as $31 \%$, The second indicator of comic media is beneficial in learning, it is still very lacking in use with a score of $43.7 \%$, criteria sometimes, and the criteria of never using comic media learning media is $28.7 \%$. The fourth indicator of habituation in reading comics in schools is the highest with the criteria, sometimes getting a score of $48.3 \%$ and the criteria of never giving refraction in reading comics at school is $34.5 \%$. The fifth indicator of the delivery of the coronavirus in learning was the highest with a score of $36.8 \%$ on the criteria often and on the criteria of never conveying about the coronavirus in learning getting a score of $11.5 \%$. The delivery indicator is more effective with comic media with the criteria, sometimes with a score of $55.8 \%$, so the conclusion is that the development of children's comics is very much needed.
\end{abstract}

Keywords: perception, children's comics, elementary school, covid-19.

\section{I.INTRODUCTION}

Coronaviruses are a large family of viruses that cause disease in humans and animals. In humans, it usually causes respiratory infections, from the common cold to severe illnesses such as Middle East Respiratory Syndrome (MERS) and Severe Acute Respiratory Syndrome (SARS). A new type of coronavirus that was discovered in humans since the outbreak emerged in Wuhan China, in December 2019, was then named Severe Acute Respiratory Syndrome Coronavirus 2 (SARS-COV2) and caused Coronavirus Disease-2019 (COVID-19) (Sudrajat, Latif, Abkoriyah \& Hidajat, 2019). COVID-19 is caused by SARS-COV2, which belongs to the same large family of coronaviruses that caused SARS in 2003, only with a different type of virus. Symptoms are similar to SARS, but the SARS mortality rate (9.6\%) is higher than COVID-19 (less than 5\%), even though the number of COVID19 cases is far more than SARS. COVID-19 also has a broader and faster spread to several countries than SARS (Astuti, 2020).

Covid-19 pandemic is a crisis in the health sector. Almost every country has experienced the impact of Covid-19. Various aspects of life in various areas are disrupting without exception in the fields of education and learning (Karmiani, 2018). The process and implementation of education and learning that should carry out must be stopped. Various policies emerged due to the existence of Covid-19 (Allo, 2020). Educational and learning activities become a big problem because many activities are not sufficient theoretically but also practically. This situation changes actions that should be carried out directly or face to face between educators and students who are stopped and limited (Zulhafizh., \& Permatasari, 2020).

The impact of this pandemic has a profound impact on learning. Circular (SE) issued by the government on March 18, 2020, all indoor and outdoor activities in all sectors have temporarily postponed reducing the spread of corona, especially in the education sector (Dewi, 2020). On March 24, 2020, the Minister of Education and Culture of the Republic of Indonesia issued Circular Number 4 of 2020 concerning Implementation of Education Policies in an Emergency for the Spread of COVID, in this Circular it was explained that the learning process is carryout at home through online / distance learning carried out to provide a learning experience meaningful to students. Learning at home can be focused on life skills education, including regarding the Covid-19 pandemic (Sobron, Bayu, \& Meidawati, 2019).

Providing knowledge to elementary school students about the coronavirus is very important to prevent its spread. Explanation to children will be complicated if the method not conveyed correctly so that the child will not understand what is conveyed by adults (Kurniaman, Noviana, Hermita, Maharani, \& Marwan, 2019). Like explaining the language of Covid-19, how to prevent it, they 


\section{Perception of the Need For Children's Comic Media Development With The Themes of Prevention of Covid-19 in Elementary School Learning}

will always wonder what kind of thing? Because they do not have enough knowledge in their schemata, interpretation will be difficult. Children's knowledge will be obtained from their family, neighbours, friends, and school or even from everything they hear (Otto, 2015). The delivery media to students must be able to translate abstract concepts into concrete concepts in learning (Noviana, Kurniaman, Munjiatun, Sismulyasih, \& Nirmala, 2020). Comic media is one of the media to communicate reality and thoughts more clearly through a combination of word and image expression (Sudjana, \& Rivai, 2013). A comic is just a picture. The images that arrange and collected into a story are mean to convey a message (Kurniaman, 2018).

Learning in elementary schools must provide a concrete explanation, by making comics as a learning medium able to visualize the Covid-19 virus by providing illustrative images that presented in the form of a series of stories that have their respective characters and characters (Toledo et al., 2014; Noviana, Kurniaman, \& Affendi, 2020). For this reason, a needs analysis needed regarding the development of children's comics for the prevention of Covid-19 in elementary schools, to provide an overview of the needs regarding the development of children's comics.

\section{LITERATURE REVIEW}

The word media comes from Latin and is the plural form of the word medium which can provide interpretation as 'intermediary'. Media is an intermediary or introduction to a message to be conveyed so that the recipient of the message can understand the message conveyed. Learning media includes physical tools used to convey meaning in the form of books, photos, pictures, videos, recorders and others. Media widely used as an intermediary for delivering messages, one of which used in learning.

Learning media are anything that can use to transmit messages (learning materials), to stimulate students' attention, interests, thoughts, and feelings in learning activities to achieve learning goals. Learning Media is an integral component of the learning system, which means that learning media cannot separate from the learning process. Without learning media, the teaching and learning process cannot occur (Sahid, 2016). Learning Media is a factor that can motivate students in the implementation of learning and can encourage students to achieve maximum learning outcomes. Learning Media is a tool that is physically used by teachers and students in teaching and learning activities so that social interactions form that cause student curiosity further to improve learning achievement (Usman, 2006).

According to Nurgiyantoro (2013), comics is a picture story with a few writings in comics to explain the image: Metalanguage sometimes there are even pictures without deafness because the pictures speak for themselves. Comics are an art form that uses immovable images arranged in such a way as to form a storyline.

Comics are the form of a story in a closely related picture-sequence designed to convey a message to its readers. The use of comic brushes with colourful illustrations, concise storylines, and realistic person-characters can appeal to students of all ages. Comic books can be used effectively by teachers to arouse students' interest in reading.

Comics, like a cartoon form that expresses characters and implements a story in a sequence that is closely related to images and design to provide entertainment to readers (Daryanto, 2013). Comics as learning media is a tool that functions to convey learning messages; in this context, learning refers to the communication process between students and learning resources (comics). As for the advantages in comics, namely that it can motivate students during the teaching and learning process, comics consist of pictures that can improve the quality of learning and arouse students' reading interest (Walyuyanto, 2005).

\section{METHODOLOGY}

This study uses a quantitative method, which is a process of finding knowledge using data in the form of numbers as a tool to analyze information about what they want to know (Hidayat, 2012). The sample of this study was 87 elementary school teachers in Pekanbaru city with random sampling to represent the research data obtained. This research instrument is in the form of questions about teachers' perceptions of the need to develop comic book media in elementary schools with material on how to prevent the spread of covid-19, with assessment criteria 1-4 (very often, often, sometimes, never). Analysis of the research data obtained from teacher responses collected through Google Form then analyzed using excel and made into tables and graphs, which are adjusted to teacher variables so that the data obtained into a percentage. After obtaining quantitative data, then the data is described following the table by calculating the average for each question item in the questionnaire, to analyze the relationship between teacher perceptions of the need for comic media in providing knowledge about Covid-19 prevention.

\section{FINDINGS AND DISCUSSIONS}

The perception of this need is preliminary data taken to see the usefulness and benefits of comic media in providing knowledge to students about preventing the spread of the covid-19 virus, which is often called the coronavirus. Delivery to elementary school students must be concrete so that it is more real and easy to imagine. This comic media provides a significant contribution to classroom learning and can transfer knowledge from abstract to concrete. For this reason, an analysis of teacher perceptions is needed by providing questions related to the need for comic media, as shown in Table 1. 
Perception of the Need For Children's Comic Media Development With The Themes of Prevention of Covid-19 in Elementary School Learning

Table 1. Teachers' Perceptions of the Need for Comic Media

\begin{tabular}{|l|l|l|l|l|l|}
\hline No & Indicator & \multicolumn{2}{l|}{ Criteria } \\
\cline { 3 - 5 } & & Very often & Often & Sometimes & Never \\
\hline 1 & The use of comic media in learning. & $0 \%$ & $13.8 \%$ & $55.2 \%$ & $31 \%$ \\
\hline 2 & Comic media is beneficial in learning. & $9.2 \%$ & $18.4 \%$ & $43.7 \%$ & $28.7 \%$ \\
\hline 3 & $\begin{array}{l}\text { Providing comic media in schools in } \\
\text { learning to read. }\end{array}$ & $3.4 \%$ & $19.5 \%$ & $60.9 \%$ & $16.1 \%$ \\
\hline 4 & $\begin{array}{l}\text { Familiarize students with reading comics } \\
\text { at school. }\end{array}$ & $1.1 \%$ & $16.1 \%$ & $48.3 \%$ & $34.5 \%$ \\
\hline 5 & $\begin{array}{l}\text { Delivering about the coronavirus in } \\
\text { learning }\end{array}$ & $24.1 \%$ & $36.8 \%$ & $27.6 \%$ & $11.5 \%$ \\
\hline 6 & $\begin{array}{l}\text { Teacher delivery is often sufficient } \\
\text { without the use of comic media. }\end{array}$ & $1.1 \%$ & $27.6 \%$ & $42.5 \%$ & $28.7 \%$ \\
\hline 7 & \begin{tabular}{l} 
Delivery using comic media is useful. \\
\hline
\end{tabular} & $2.3 \%$ & $5.8 \%$ & $55.8 \%$ & $36 \%$ \\
\hline
\end{tabular}

It can be seen in table 1 that the teacher's perception explains that the use of comic media in learning in elementary schools is the highest with the criteria of $55.2 \%$, and in the category of never using comic media as much as $31 \%$. The second indicator of comic media is beneficial in learning. It is still very lacking in use with a score of $43.7 \%$, criteria sometimes, and the criterion of never using comic media learning media is $28.7 \%$. The third indicator of comic media in schools in reading learning is the highest with the criteria of $60.9 \%$ and the criteria of never providing comic media in schools in learning to read by $16.1 \%$. The fourth indicator of habituation in reading comics in schools is the highest with the criteria, sometimes getting a score of $48.3 \%$ and the criteria of never giving refraction in reading comics at school is $34.5 \%$. The fifth indicator to delivery coronavirus in learning was highest with a score of $36.8 \%$ on the criteria often and on the criteria of never conveying about the coronavirus in learning getting a score of $11.5 \%$. The sixth indicator of teacher delivery is often less useful without using the highest comic media with a score of $42.5 \%$ on the criteria sometimes, and teacher delivery is often less effective without using the lowest comic media with a score of $1.1 \%$ on the criteria frequently. The seventh indicator of delivery using comic media is more effective with the highest score of $55.8 \%$ on the occasional criteria and delivery using comic media is more effective with the lowest score of $2.3 \%$ on the criteria, often more clearly, it will show in the graph below.

\section{PERCEPTION OF THE NEED FOR COMIC MEDIA}

$$
\text { III Never i Sometimes III Often III Very often }
$$

Delivery using comic media is useful.

Teacher delivery is often sufficient without the use of comic media.

Delivering about the coronavirus in learning

Familiarize students with reading comics at school.

Providing comic media in schools in learning to read.

Comic media is beneficial in learning.

The use of comic media in learning.

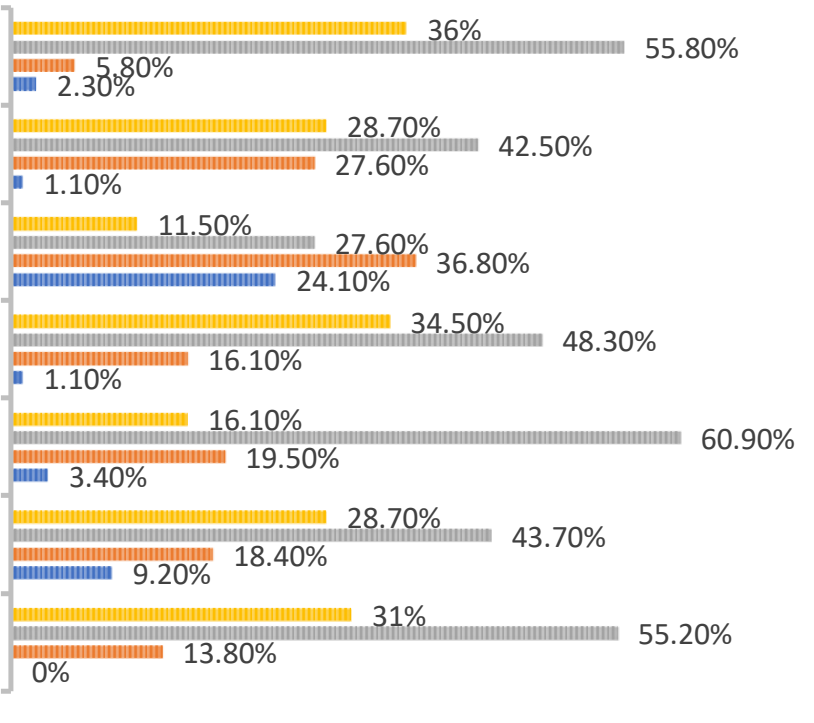

Figure 1. Perceived Graph of Comic Media Needs

Good learning provides knowledge that focuses on very low reading literacy (Panyajamorn, T., Suanmali, S., Kohda, Y., Chongphaisal, P., \& Supnithi, T, 2018). The motivation of students in elementary schools in reading is influenced by several learning 


\section{Perception of the Need For Children's Comic Media Development With The Themes of Prevention of Covid-19 in Elementary School Learning}

factors that do not emphasize exciting learning, as seen from the data, 3.4\% of teachers provide learning using learning media. Reading literacy is greatly influenced by children's experiences (Au \& Kawakami, 1991; Delgado-Gaitan, 1990; Ladson-Billings, 1994; Lopez, 2020) so that a teacher must increase reading motivation in various ways in learning. Providing reading texts must provide vital information to prevent the spread of Covid-19 so that currently, Indonesia stops direct learning from being replaced with online learning.

The main thing learning media (Kurniaman \& Sismulyasih Sb, 2019) must provide information for students to get an explanation about the dangers of covid-19 so that students can understand the information that will be conveyed by the teacher. This children's comic media provides explanations in the form of the abstract into concrete so that it can provide clear explanations to children. This comic provides many advantages for students besides getting information and can provide fun and entertainment for readers (Hasan, 2017). However, this gift significantly less given to students after giving a survey to the teacher with 55.80\% with the criteria, sometimes even though the teacher very knows the use of this medium. Teachers are also deficient in providing understanding to students about the coronavirus in learning so that students are low on knowledge of the dangers of the virus and how to prevent it.

The teacher's perceptions of learning comic media are very helpful in learning, so that students are faster in understanding the writing that will be conveyed by the teacher with the presence of illustrated images (Azizah \& Sari, 2020). Learning is essentially a process of interaction between students and their environment, so that there is a change in behaviour towards the better and the combination is composed of human elements, materials, facilities, equipment and procedures that influence each other to achieve learning goals (Hamalik, 2012). In this interaction, there are many factors that influence it, both internal factors that come from individuals and external factors that come from the environment. Teachers in carrying out the learning process must be able to choose, design and apply good learning strategies that are in accordance with the characteristics of the subject matter and student characteristics. In addition, it is also necessary to consider the activeness of students in carrying out learning (Candra \& Yanto, 2020). This is because a good learning process is a student-centered learning process, where students play a more dominant role in the learning process (Sukardi, Puyada, Wulansari, \& Yanto, 2017).

\section{CONCLUSION}

Teachers' need for comic media very much need in carrying out learning in elementary schools. Explanations about the prevention of covid-19 rarely given to students by connecting them to class material. So with this comic media, it can provide concrete explanations because each explanation give an illustrated image.

\section{REFERENCES}

1) Au, K. H., \& Kawakami, A. J. (1991). Culture and ownership: Schooling of minority students. Childhood Education, 67, 280-284.

2) Astuti, N.P.E. (2020). Optimizing Children Gross Motoric Skill By Yoga Asana Practice In Covid-19 Pandemic. Jurnal PAJAR (Pendidikan dan Pengajaran), 4(5), 926-936. DOI : http://dx.doi.org/10.33578/pjr.v4i5.8032.

3) Allo, M. D. G. (2020). Is the Online Learning Good in the Midst of Covid-19 Pandemic? The Case of EFL Learners. Jurnal Sinestesia, 10(1), 1-10.

4) Azizah \& Sari, A.W. (2020). The Application Model Learning Games Abc To Improve Result Of Learning. Jurnal PAJAR (Pendidikan dan Pengajaran), 4(5), 895-903. DOI : http://dx.doi.org/10.33578/pjr.v4i5.7998.

5) Candra, O \& Yanto, D.T.P. (2020). The Active Learning Strategy "Everyone Is A Teacher Here" To Improve Student Learning Outcomes. Jurnal PAJAR (Pendidikan dan Pengajaran), 4(3), 616-623.

DOI : http://dx.doi.org/10.33578/pjr.v4i2.7991.

6) Dewi, W. A. F. (2020). Dampak Covid-19 Terhadap Implementasi Pembelajaran Daring di Sekolah Dasar. Edukatif : Jurnal Ilmu Pendidikan, 2(1), 55-61.

7) Daryanto. (2013). Media Pembelajaran. Yogyakarta: Gava Media.

8) Delgado-Gaitan, C. (1990). Literacy for empowerment: The role of parents in children's education. New York: Falmer.

9) Hidayat, A. (2012). Pengertian dan Penjelasan Penelitian Kuantitatif. https://www.statistikian.com/2012/10/penelitian-kuantitatif.html.

10) Hasan, A. (2017). The Effect of Directed Reading Thinking Activity (DRTA) Method on Students' Reading Comprehension for State Islamic Senior High School. Journal of English and Arabic Language Teaching, 8(2), pp. 140148.

11) Hamalik, O. (2012). Perencanaan Pembelajaran Berdasarkan Pendekatan Sistem. Jakarta: Bumi Aksara.

12) Karmiani, S. (2018). Penggunaan Media Komik Berbahasa Inggris Sebagai Upaya Meningkatkan Kemampuan Membaca Pemahaman Bahasa Inggris Pada Siswa Kelas VIII SMPN 3 Teluk Kuantan. Jurnal PAJAR (Pendidikan dan Pengajaran). 2(6), 883-890. http://dx.doi.org/10.33578/pjr.v2i6.6514. 
Perception of the Need For Children's Comic Media Development With The Themes of Prevention of Covid-19 in Elementary School Learning

13) Kurniaman, O. (2018). Buku Ajar Apresiasi Sastra Anak untuk Mahasiswa Pendidikan Guru Sekolah Dasar. Pekanbaru: UR Press.

14) Kurniaman, O., Noviana, E., Hermita, N., Maharani, A.S., \& Marwan, A. (2019). Development of Critical Thinking Test Instrument Reading Using The Graphic Organizer Media. Jurnal PAJAR (Pendidikan dan Pengajaran), 3(5), 974-802. DOI : http://dx.doi.org/10.33578/pjr.v3i5.7809.

15) Kurniaman, O., \& Sismulyasih Sb, N. (2019). The Influence of The Big Book Media Has The Character of Conservation in Early Reading. ELS Journal on Interdisciplinary Studies on Humanities, 2(1), 141-147.

16) Lopez, M. M. (2020). Linking Community Literacies to critical literacies through community language and literacy mapping. Teaching and Teacher Education, 87, 1-9.

17) Ladson-Billings, G. (1994). The dreamkeepers: Successful teachers of African American children. San Francisco: JosseyBass.

18) Noviana, E., Kurniaman, O., Munjiatun., Sismulyasih Sb, N., \& Nirmala, S. D. (2019). Why Do Primary School Students Need Disaster Mitigation Knowledge? (Study Of The Use Of Koase Comics In Primary Schools). International Journal Of Scientific \& Technology Research, 8(11), 216-221.

19) Nurgiantoro, Burhan. 2013. Sastra Anak. Yogyakarta: Gadjah Mada University Press.

20) Noviana, E., Kurniaman, O., \& Affendi, N. (2020). KOASE: Disaster Mitigation Learning Media in Elementary School. Tadris: Jurnal Keguruan dan Ilmu Tarbiyah, 5(1), 11-25. DOI: 10.24042/tadris.v5i1.5183.

21) Panyajamorn, T., Suanmali, S., Kohda, Y., Chongphaisal, P., \& Supnithi, T. (2018). Effectiveness Of E-Learning Design And Affecting Variables In Thai Public Schools. Malaysian Journal of Learning and Instruction, 15 (1), 1-34.

22) Otto, B. (2015). Perkembangan Bahasa pada Anak Usia Dini. Jakarta: Kencana.

23) Sudrajat, T., Latif, H., Abkoriyah, H., \& Hidajat, D. (2019). Apakah Coronavirus dan Covid 19 itu? https://stoppneumonia.id/informasi-tentang-virus-corona-novel-coronavirus/.

24) Sobron, A. ., Bayu, R., \& Meidawati. (2019). Persepsi Siswa Dalam Studi Pengaruh Daring Learning Terhadap Minat Belajar IPA. SCAFFOLDING: Jurnal Pendidikan Islam Dan Multikulturalisme.

25) Sukardi, S., Puyada, D., Wulansari, R. E., \& Yanto, D. T. P. (2017). The validity of interactive instructional media on electrical circuits at vocational high school and technology. The 2nd INCOTEPD, 2017, 21-22, retrieved from http://eprints.uny.ac.id/id/eprint/58200.

26) Sudjana, N., \& Rivai A. (2013). Media Pengajaran. Bandung: Sinar Baru Algensindo.

27) Sahid. (2016). Pengembangan Media Pembelajaran Berbasis Multimedia dalam Konsep Sistem Indera pada Siswa Kelas XI SMA. Jurnal Pendidikan Biologi, 69-80.

28) Toledo, M. A., Yangco, R. T., \& Espinosa, A. A. (2014). Media Cartoons: Effects on Issue Resolution in Environmental Education. International Electronic Journal of Environmental Education, 4(1), 19-51. https://doi.org/10.18497/iejeegreen.99250.

29) Usman. (2006). Peran Media Pembelajaran dalam Meningkatkan Prestasi Belajar Siswa. Jurnal Pendidikan Manajemen Perkantoran.

30) Walyuyanto. (2005). Komik sebagai Media Komunikasi Visual Pembelajaran. 45-55.

31) Zulhafizh., \& Permatasari, S. (2020). Developing Quality Of Learning In The Pandemic Covid-19 Through Creative And Critical Thinking Attitudes. Jurnal PAJAR (Pendidikan dan Pengajaran), 4(5), 937-949.

DOI : http://dx.doi.org/10.33578/pjr.v4i5.8080. 